\title{
PROGRESSIVE FAMILIAL CHOREOATHETOSIS WITH CUTANEOUS TELANGIECTASIA
}

\author{
BY
}

\section{CHARLES E. WELLS and G. MILTON SHY}

\begin{abstract}
From the Medical Neurology Branch, National Institute of Neurological Diseases and Blindness, National Institutes of Health, Public Health Service, Department of Health, Education, and Welfare, Bethesda, M.D., U.S.A.
\end{abstract}

Progressive athetosis beginning in childhood after the neonatal period is a rare clinical phenomenon which has been further clarified into only a small number of distinct clinical entities. The purpose of this communication is to direct attention to the incidence of this phenomenon in two sisters, each of whom subsequently developed progressive bilaterally symmetrical cutaneous telangiectasia.

The $\mathbf{L}$ family is composed of healthy non-consanguinous parents (ages 45 and 54 years) whose only children are three girls, all of whom are affected with progressive neurological disorders. The two younger siblings present a similar clinical syndrome, whereas the oldest manifests a different disease pattern. The only other known affection of the nervous system within the family is Parkinson's disease which occurred in three of the paternal forebears (Fig. 1).

The oldest child (IV-d) appears to have a different disorder clinically from that in the two younger. This child, now 14 years of age, was born after a normal period of gestation but was cyanotic at birth. She was not considered abnormal, however, until after an episode of fever, diarrhoea, and lethargy at 6 months of age. She has been regarded as retarded, both physically and mentally, since that time. She learned to walk only after special training and this ability has regressed within the past several years. Speech has never been purposeful. Psychological studies have shown her to be at the idiot level. The disorder appears to be progressive.

On examination* the child was very over-active and was continually repeating stereotyped phrases. She never appeared to fix her attention on any person or object. No nystagmus was present. Vision was preserved. The extremities were symmetrical and displayed no atrophy. Talipes valgus were present. Marked resistance to passive movement of the

* We are indebted to Dr. William J. Logue of the Pennhurst State School, Spring City, $\mathrm{Pa}$., for permission to examine this patient. clasp-knife type was noted bilaterally in the upper and lower extremities, more marked on the left. The lower extremities were strongly adducted with some scissoring. Strength was well preserved. No choreo-athetotic movements were evident. Ankle clonus was present bilaterally and the deep tendon reflexes were active and equal on the two sides. There were no skin lesions in any way resembling those in her younger sisters.

The two younger children present similar clinical syndromes which differ from that in the eldest. The onset of the disorder in the two younger siblings was at ages 5 and 7 . Its inception was characterized by difficulty in motility in hitherto normal children. Abnormal movements of the trunk and extremities while at rest were then noted, followed by progressive difficulty with speech. Two to three years after the appearance of the above symptoms, cutaneous lesions were first observed in each of the children. The distribution of these lesions was similar in each. These were most evident below the eyes, in the antecubital and popliteal fossae, and over the dorsum of the hands, forearms, legs, feet, and the anterior neck region.

Physical examination revealed choreo-athetosis involving the face, tongue, trunk, and extremities. Inconstant difficulties in conjugate ocular deviation in all directions was noted. A staggering gait with propulsive characteristics was observed, along with poor coordination which was not out of proportion to the involuntary movements. Examinations earlier in the disease by other investigators indicated that the amount of incoordination may have been excessive in proportion to the involuntary movements then apparent. Strength was normal throughout and skeletal musculature well preserved. No increase or decrease in resistance to passive movement was observed. Excepting the ocular movements and athetosis of the tongue, face, and neck, examination of the cranial nerves revealed no abnormality. Sensation remained intact. The deep tendon reflexes 


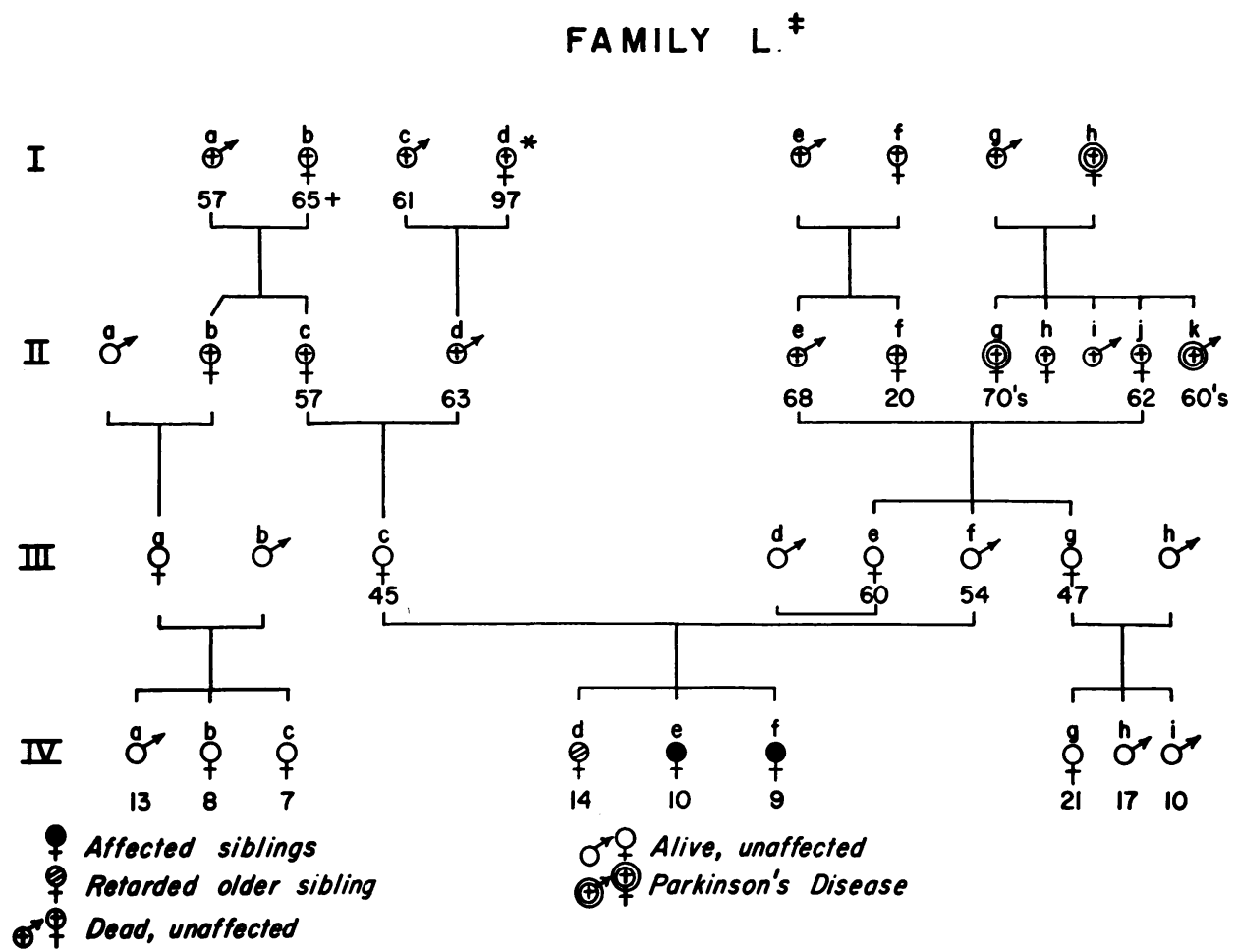

FIG. 1.-Pedigree of family $L$.

\footnotetext{
$\ddagger$ Numbers below the figures indicate ages at present or at death, when known.

* I- $d$ 's oldest brother developed mental retardation and abnormalities of gait and speech following measles at 2-3 years of age. No other neurological disorders known in her family. Causes of death, when known.

I- $a=$ cerebrovascular accident

$\mathrm{I}-\mathrm{b}=$ hypertension, cerebrovascular accident

$\mathbf{I}-c=$ uraemia

$\mathbf{I}-\boldsymbol{h}=$ Parkinson's disease
}

were absent while the abdominal reflexes remained active and the plantar response, downgoing. Mentation in both children appeared normal. Speech was noticeably slow and indistinct, associated with facial grimacing and respiratory irregularity. Multiple minute vascular channels which blanched on pressure were present in the conjunctivae, in the skin under the eyes, across the bridge of the nose, in the periclavicular area, antecubital and popliteal fossae, and on the dorsum of the forearm, hand, leg, and foot.

The remainder of the physical examination revealed no abnormality except hepatomegaly in the youngest child. Clinical pathological investigations revealed no abnormalities.

\section{Case Histories}

Case IV-e (Age 10 Years, 8 Months). - The birth and early development were entirely normal. The child began to walk at 11 months of age and to talk at 16-18

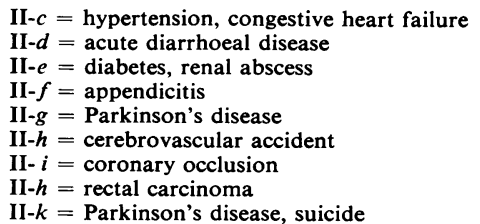

months. She always appeared slightly clumsy to her parents, but this was not considered to be of unusual degree. At 5 years it was first noted that she had difficulty in holding her head steady. Within the year her parents observed that she never walked slowly but always appeared to run from one spot to another. She developed difficulties with balance, tending to totter from side to side while walking, and she began to spill fluids from glasses. At 6 years slow, undulating movements of the trunk and extremities while at rest were seen, and her speech became slurred and hard to understand. By 7 years, facial grimacing had made its appearance, and her handwriting showed deterioration.

These difficulties have been progressive since the onset, though the advancement appears to have been slowed during the past year. At present the child is severely disabled. Her gait is quick-stepped, with much staggering in all directions, She is able to feed and to dress herself with much effort. She attends school where no evidence of any mental deterioration has been noted.

Within the past one or two years, many small bright red spots which blanche on pressure have been noted in 

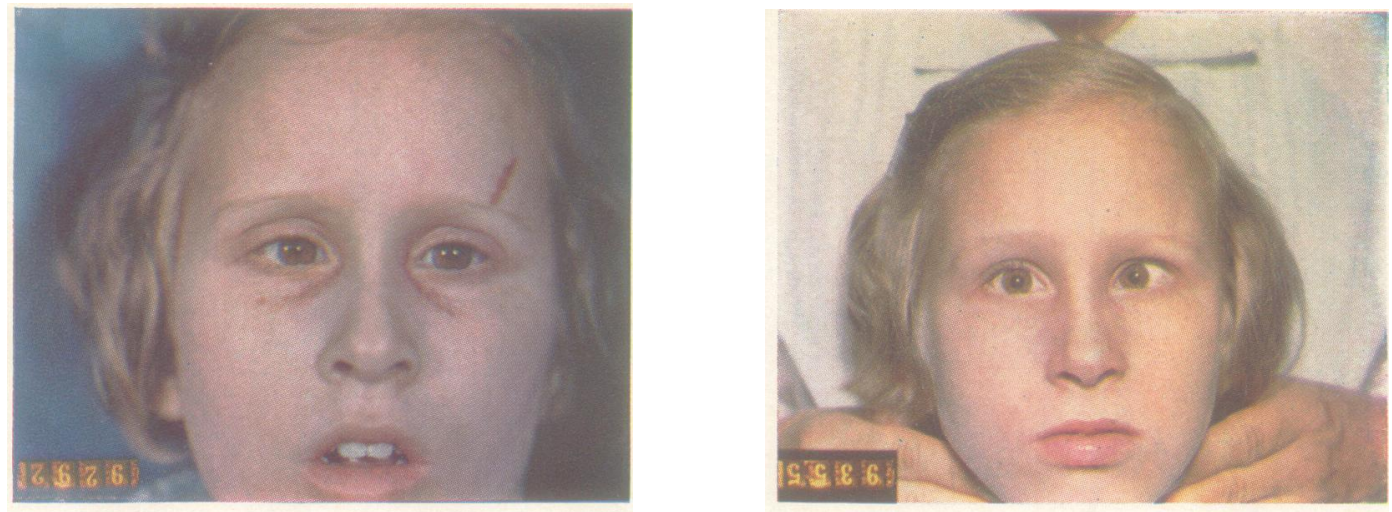

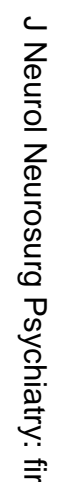
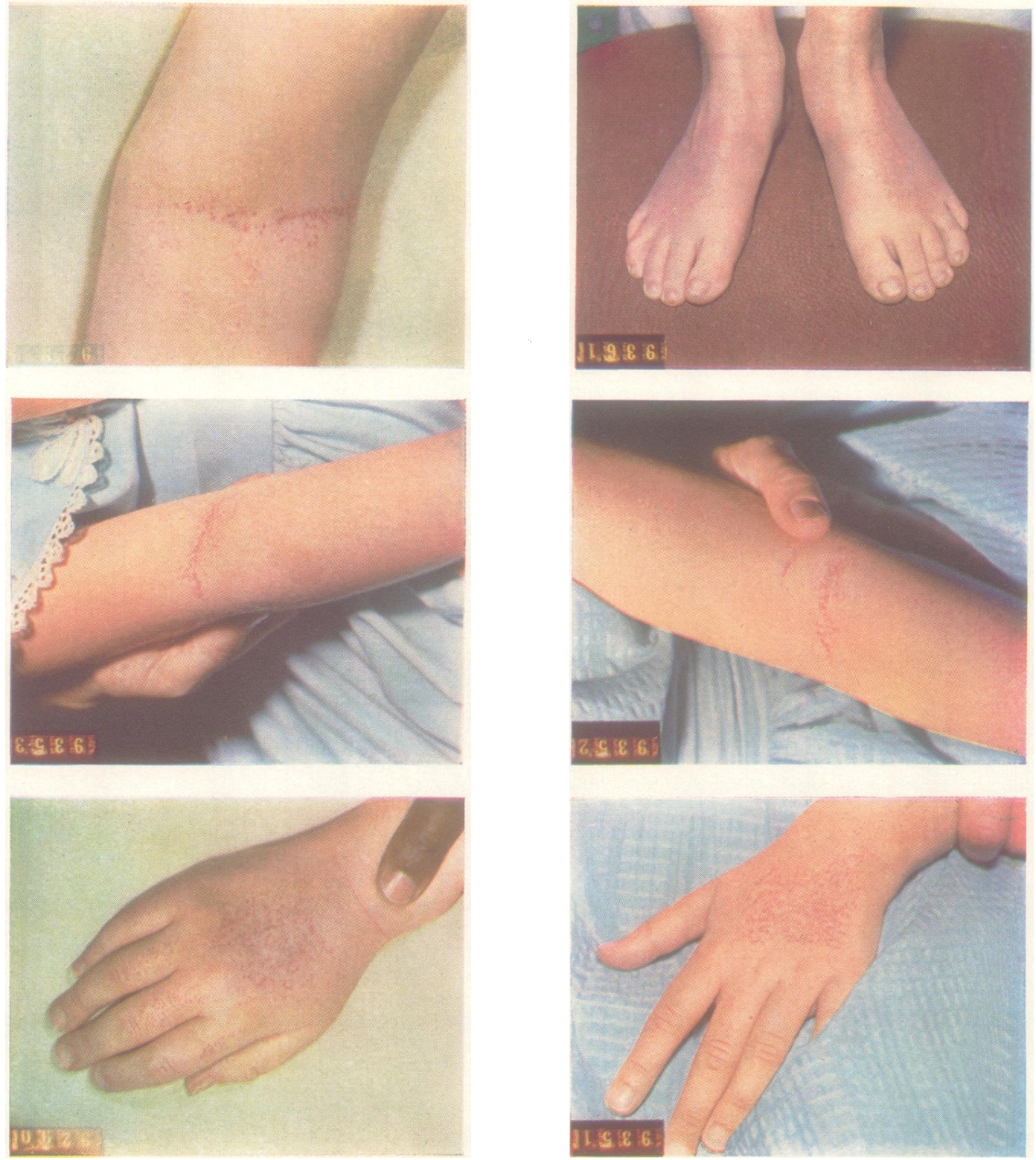

FIG. $2(a, b, c, d)$.-Typical skin lesions in Patient IV-e.

FIG. $3(a, b, c, d)$.-Typical skin lesions in Patient IV-f.

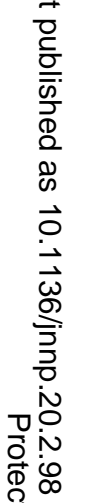

官 음

으무

3

ญ

它 흔 위

8

言

응

¿

옹

疍

亏亏ํำ

$\frac{10}{3}$

을

오

궁

ב

N

N

N

О

임 
her skin. These have developed below the eyes, across the bridge of the nose, about the neck, in the antecubital and popliteal fossae, and over the dorsum of the forearms, hands, legs, and feet. The parents are quite certain that these were not present earlier in life.

The past history and systemic review were unremarkable.

General physical examination was not significant except for the skin lesions (Fig. 2). These consisted of rather localized reticular areas of telangiectasia, which blanched on pressure, in the bulbar conjunctivae, beneath the eyes, over the bridge of the nose, the anterior and upper chest, in the antecubital and popliteal fossae, and over the dorsum of the forearms, hands, legs, and feet. Dr. Eugene Van Scott, consultant in dermatology, observed that these lesions did not resemble those seen in the Osler-Rendu-Weber syndrome, Sturge-WeberDimitri syndrome, or von Hippel-Lindau syndrome.

No Kayser-Fleischer ring could be seen either by naked eye or slit-lamp examination. The spleen and the liver were not enlarged.

On neurological examination the patient was intelligent and alert. Psychological studies revealed an average to high average range of intellectual function. Cranial nerve examination showed limitation of upward conjugate gaze. Lateral conjugate gaze was at times limited, with some nystagmoid jerks. Occasionally dysconjugate lateral movements were seen. There was a slight right esotropia. The face was somewhat mask-like and was contorted by frequent grimaces. The tongue was involved in almost continuous athetoid movements. Speech was slurred and sometimes " mushy", associated with disturbances in the rhythm of respiration. At rest the trunk and head swayed continuously but irregularly in all directions. All four extremities were involved in the flowing, undulating involuntary movements which were asymmetrical at a given time but approximately equal on the two sides. These slow movements were occasionally interrupted by quick single movements causing momentary displacement of the part involved, for example, the finger or shoulder. On standing, she could maintain balance only with the feet separated widely apart. Walking was of a propulsive character with much staggering, the legs being thrown out wildly at the sides, the upper extremities being abducted into strangely contorted postures in an effort to maintain balance.

The muscles were well developed and without apparent weakness. Tone appeared normal within the limits imposed on the examination by the involuntary movements. Fine finger movements were slightly slowed while rapid rhythmic movements were markedly so. Associated movements occurred in the contralateral extremity on voluntary contraction of the homolateral limb. Finger-to-nose, point-to-point, and heel-to-shin tests were performed poorly, with much overshooting and undershooting; to dissociate this disability from the involuntary movements was impossible.

No sensory abnormalities were demonstrated. Deep tendon reflexes were not elicited. Superficial abdominal reflexes were active and equal. Plantar responses were downgoing.

Skull radiographs revealed no abnormalities. The electroencephalogram showed a diffuse dysrhythmia. A serological test for syphilis was negative. Urine analysis revealed no significant abnormalities. Haematological studies (including haematocrit, white blood cell and differential count, sedimentation rate, and platelet count) were normal. The blood group was $\mathrm{B}, \mathrm{Rh}$ positive. Studies for evaluation of liver function (alkaline phosphatase, cephalin flocculation, thymol turbidity, total protein, albumin-globulin ratio, prothrombin time, serum bilirubin, cholesterol, bromsulphalein) were within normal limits, as were blood urea nitrogen and fasting blood sugar. Studies for evidence of hepatolenticular degeneration (total urinary amino-acids, urinary copper, serum copper, ceruloplasmin, serum uric acid) were negative. In addition, specific quantitative and qualitative urinary amino-acid and sugar studies disclosed no abnormalities. Spinal fluid examination showed normal cells, protein, globulin, and a normal colloidal gold curve.

Case IV-f (Age 9 years, 6 Months).-The birth and early development were entirely normal. The child began to walk and to talk at the usual ages and never displayed any clumsiness. She was considered to be entirely normal until approximately 7 years of age when her parents noted her to have difficulty with balance while walking. This staggering increased in severity and her steps became much quicker than previously. Involuntary movements then appeared, taking the form of quick, non-repetitive, asymmetrical jerks involving a part of a segment or a segment of the extremities associated with slow undulating movements of the extremities and the trunk. The quick components of the abnormal movements were more prominent than they were in her older sister. Shortly thereafter her speech became slurred and difficult to understand.

Progression of the symptoms has been somewhat faster in this child than in her older sibling. At present she has much difficulty with walking. She can feed herself but can only partially dress herself. She attends school where her scholarship is poor but with no suggestion of mental deterioration since the onset of the illness.

Within the past year skin lesions of exactly the same nature and distribution as those present in her older sister have appeared.

The past history is unremarkable except for the presence of a left esotropia of several years duration. The systemic review was negative.

On examination of the skin, lesions of exactly the same type as are present in her older sister were noted (Fig. 3). These were present in precisely the same distribution, though of less severity. The liver was palpable $1 \mathrm{~cm}$. below the right costal margin; it was smooth and not tender. No Kaiser-Fleischer ring could be seen either directly or on slit-lamp examination.

On neurological examination the patient was mentally clear and alert. Psychological studies revealed a function at the lower limits of the average range. The cranial nerve examination showed a left esotropia, some limitation of upward gaze, and intermittent limitations in lateral conjugate gaze in either direction with occasional dysconjugate movements. Expressive facial movements were reduced and there were frequent grimaces. The 
tongue showed continuous athetoid movements. Speech was slow and slurred and was associated with respiratory irregularities.

The child could maintain herself in the standing position with the heels held together. While standing or sitting the head and trunk swayed markedly. Two types of abnormal movements of the extremities could be distinguished. The first consisted of irregular, asymmetrical quick movements which were non-repetitive in the same muscle groups, involved either single or entire muscle groups, and might or might not cause segmental displacement. The second consisted of slow, irregular, non-repetitive, asymmetrical flowing movements, most severe in the fingers and hands. When walking, she threw her feet out in an awkward manner and tottered from side to side, while the arms were abducted in strange postures in a partially effectual effort to maintain balance.

No evidence of muscular atrophy or weakness was found. There was a question of minimal increase in tone, evaluation being quite difficult due to the constancy of the abnormal movements. Fine movements were considerably slowed. Attempts at rapid rhythmic movements resulted in decomposition of the usual movement pattern. Point-to-point, finger-to-nose, and heel-to-shin tests were ill performed, with much overshooting and undershooting which could not be dissociated from the abnormal movements in the examination.

No sensory abnormalities were observed. Deep tendon reflexes were not elicited. Superficial abdominal reflexes were active and equal on the two sides, and plantar responses were downgoing.

The same laboratory examinations were performed in this patient as in her older sister. No further abnormalities were uncovered in any of these studies.

\section{Discussion}

The onset of athetosis at the ages of 5 and 7 removes from diagnostic consideration the largest group of involuntary movements of childhood, i.e., those which occur on or about the neonatal period (double athetosis, cerebral diplegia, and kernicterus). The duration of the illness, its steady progression, and the absence of signs and symptoms such as arthralgia, subcutaneous nodules, cardiovascular disease, and elevated sedimentation rate, also make the choreo-athetosis associated with rheumatic fever unlikely.

Therefore from a diagnostic standpoint we are confronted with a progressive degenerative disorder of the nervous system occurring in three siblings and characterized in two by choreo-athetosis and cutaneous telangiectasia. We have been unable to find such a syndrome previously described. If one assumes that these two processes (choreo-athetosis and cutaneous telangiectasia) are unrelated and that two concurrently progressive disorders are present, then several diagnostic possibilities must be considered: (1) A post-encephalitic disorder of the extrapyramidal system, (2) a toxic disorder of the extrapyramidal system, (3) a progressive disorder of the extrapyramidal system.

A post-encephalitic disorder must certainly be considered in the eldest sibling. Since the abnormality was first noted following an infectious process, a post-encephalitis abnormality is possible in this child; if, however, all three siblings are considered, there is strong argument against such an origin. The questionable aetiological episode in the eldest antedated the neonatal period of either of the two younger children. No history of antecedent infection could be obtained in these younger children, and furthermore the onset of their neurological involvement was separated by over two years. Lastly, the likelihood of an identical syndrome following encephalitis in two afflicted members of a family would be distinctly unusual.

The likelihood of this being a toxic disorder is slight in view of its onset at widely separated periods. We were unable to obtain a history of exposure to either carbon monoxide or manganese.

Progressive disorders involving the basal ganglia 0 have been described by Creutzfeldt (1920) and Jakobs iv (1921) (recently reviewed by de Ajuriaguerra $\mathbb{\Phi}_{\infty}$ Hécaen, Layani, and Sadoun, 1953; Lhermitte Cornil, and Quesnel, 1920; Lhermitte and McAlpine $\frac{\circ}{-}$ 1926; and Ross, 1955). The onset in each of these 3 disorders was reported to be in adult life. To oup knowledge such disorders have not been observed in children.

There remains for diagnostic consideration only a group of rare progressive disorders of infancy and childhood in which the extrapyramidal system may be involved: (1) Hepatolenticular degeneration, (2) progressive atrophy of the globus pallidus, (3) dystonia musculorum deformans, (4) PelizaeusMerzbacher disease, (5) Hallervorden-Spatz disease, and (6) status dysmyelinatus. The clinical characteristics which distinguish these disorders are listed in Table $\mathbf{I}$.

The most common progressive degenerative disorder of the extrapyramidal system in childhood is hepatolenticular degeneration (Wilson, 1912). Within the past decade, abnormalities in copper and protein metabolism and in amino-acid excretion have been described in this disorder (Uzman and DennyBrown, 1948; Cartwright, Hodges, Gubler, Mahoney, Daum, Wintrobe, and Bean, 1954; Bush, Mahoney, Markowitz, Gubler, Cartwright, and Wintrobe, 1955). All such studies (serum copper, urinary copper, serum ceruloplasmin, urinary amino-acids) were within normal limits in these two patients. This would appear effectively to rule out a diagnosis of hepatolenticular degeneration in our two patients. 
TABLE I

PROGRESSIVE EXTRAPYRAMIDAL DISORDERS OF CHILDHOOD

\begin{tabular}{|c|c|c|c|c|c|c|}
\hline Syndrome & $\begin{array}{c}\text { Hepato- } \\
\text { Lenticular } \\
\text { Degeneration }\end{array}$ & $\begin{array}{c}\text { Progressive } \\
\text { Atrophy of } \\
\text { Globus Pallidus }\end{array}$ & $\begin{array}{l}\text { Dystonia } \\
\text { Musculorum } \\
\text { Deformans }\end{array}$ & $\begin{array}{l}\text { Pelizaeus- } \\
\text { Merzbacher }\end{array}$ & $\begin{array}{l}\text { Hallervorden- } \\
\text { Spatz }\end{array}$ & $\begin{array}{c}\text { Status } \\
\text { Dysmyelinatus }\end{array}$ \\
\hline Onset & 1st-4th decade & $6-30$ years & $5-15$ years & Infancy & Childhood & Infancy \\
\hline Duration & $\begin{array}{l}\text { Moderate } \\
(2-20 \text { years })\end{array}$ & $\begin{array}{l}\text { Moderate } \\
(10-20 \text { years }\end{array}$ & Long & $\begin{array}{l}\text { Long } \\
\text { (to } 52 \text { years) }\end{array}$ & $\begin{array}{l}\text { Moderate } \\
\text { (death at } \\
16-27 \text { years) }\end{array}$ & $\begin{array}{l}\text { Moderate } \\
\text { (death at } \\
10-20 \text { years) }\end{array}$ \\
\hline Mental Power & ? Preserved & Preserved & Preserved & \pm & Demented & $\pm ?$ \\
\hline $\begin{array}{l}\text { Neurological } \\
\text { Picture }\end{array}$ & $\begin{array}{l}\text { Tremor } \\
\text { Choreoathetosis } \\
\text { Wing beating } \\
\text { Rigidity } \\
\text { Spasms } \\
\text { K-F ring } \\
\text { Cirrhosis }\end{array}$ & $\begin{array}{l}\text { J u v e n i l e } \\
\begin{array}{l}\text { Parkinson's } \\
\text { disease }\end{array}\end{array}$ & $\begin{array}{l}\text { Prolonged con- } \\
\text { tractions of } \\
\text { axial muscles }\end{array}$ & $\begin{array}{l}\text { Nystagmus } \\
\text { Rigidity } \\
\text { Incoordination } \\
\text { Pareses } \\
\text { Mask-like facies } \\
\text { Slowed speech } \\
\text { movement } \\
\text { Pyramidal signs }\end{array}$ & $\begin{array}{l}\text { Rigidity } \\
\text { Pareses } \\
\text { Slowed speech } \\
\text { Contractions } \\
\text { Choreoathetosis }\end{array}$ & $\begin{array}{l}\text { Rigidity } \\
\text { Athetosis }\end{array}$ \\
\hline Transmitted & Familial & $\begin{array}{l}\text { Somet imes } \\
\text { familial }\end{array}$ & $R \underset{\text { familial }}{\mathbf{a}} \mathbf{r}$ e $\mathbf{y}$ & Sex linked & Familial & Sporadic \\
\hline Pathology & $\begin{array}{l}\text { Nerve cell loss } \\
\text { in b a s a 1 } \\
\text { ganglia and } \\
\text { cortex. Wide- } \\
\text { spread gliosis }\end{array}$ & $\begin{array}{l}\text { Degeneration } \\
\text { of nerve cells } \\
\text { in globus } \\
\text { pallidus. }\end{array}$ & $\begin{array}{l}\text { Status marma- } \\
\text { ratus. De- } \\
\text { generation } \\
\text { of nerve cells } \\
\text { in b a s a 1 } \\
\text { ganglia }\end{array}$ & $\begin{array}{l}\text { Demyelination } \\
\text { with islands } \\
\text { of preserved } \\
\text { myelin. Rela- } \\
\text { tive sparing of } \\
\text { cortex }\end{array}$ & $\begin{array}{c}\text { Iron deposition } \\
\text { in globus } \\
\text { pallidus, sub- } \\
\text { stantia nigra, } \\
\text { and vascular } \\
\text { w a lls of } \\
\text { basal ganglia }\end{array}$ & $\begin{array}{l}\text { Demyelination } \\
\text { of striopal- } \\
\text { lidal, thala- } \\
\text { mopallidal, } \\
\text { pallidoluy- } \\
\text { sial and H(1) } \\
\text { tracts }\end{array}$ \\
\hline Clinical Pathology & $\begin{array}{l}\text { Amino-aciduria } \\
\text { Ceruloplas- } \\
\text { min } \downarrow \text { Serum } \\
\text { copper } \downarrow \text { Urine } \\
\text { copper } \uparrow\end{array}$ & $?$ & $?$ & $?$ & $?$ & $?$ \\
\hline
\end{tabular}

The absence of tremor and rigidity in our two patients makes unlikely the diagnosis of progressive atrophy of the globus pallidus (juvenile paralysis agitans) (Hunt, 1917; Denny-Brown, 1946).

Many clinical patterns have in the past been placed within the dystonia musculorum deformans category. If one accepts Herz' (1944) criterion for the diagnosis of dystonia musculorum deformans, based on clinical and pathological studies, then prolonged contractions of the axial musculature are prerequisite for the diagnosis. This criterion was not satisfied by our patients. Furthermore the familial occurrence of dystonia musculorum deformans is rare.

In 1885 Pelizaeus reported a progressive neurological disorder involving five members of a single family. In 1910 Merzbacher presented a further report on the same family in which 14 members of four generations were afflicted, 12 being males and two females, together with the pathological findings in one case. The disease characteristically appeared in the male and was transmitted by the female. Symptoms were usually first noted at about 3 months of age, though onset at 43 years has been reported (Löwenberg and Hill, 1933). Its occurrence in females and its non-familial incidence have also been recorded (Scheftel, 1931; Löwenberg and Hill, 1933). Nevertheless, a diagnosis of PelizaeusMerzbacher disease in our two patients would appear unlikely, due to its late onset and the absence of mental deterioration, rigidity, paresis, and pyramidal signs. Such a diagnosis, however, could not be ruled out definitely for the eldest child.

Hallervorden and Spatz (1922) described a progressive disorder with onset in childhood involving five female siblings, characterized by spasticity, paresis, and contractions of the extremities associated with mental deterioration and choreoathetosis. Against such a diagnosis in our two patients is the absence of paresis, contractures, and spasticity and the presence of well preserved mental faculties.

Status dysmyelinatus (Vogt and Vogt, 1920, abstracted at length by Winkelman, 1923) is an extremely rare disorder characterized by the onset in infancy of progressive rigidity and athetosis. It has been reported associated with convulsions (the Vogts' first case) and with dystonia (Alexander's second case, 1942). It has not been reported to occur familially. The late onset, absence of rigidity, and familial nature of the disease in our patients argue against this diagnostic possibility.

Thus, even if the presence of two concomitantly progressive disorders is accepted, it is difficult to place the neurological involvement with certainty within any of the previously defined entities. If, on the other hand, the premise of two independent processes in these two patients is rejected, then the question must arise as to the nature of the disease 
which is manifested by progressive choreo-athetosis associated with cutaneous telangiectasia. Neurologically, these two patients present definite evidence of disease involving the extrapyramidal system, together with dorsal root or peripheral nerve involvement (absent deep tendon reflexes), and possibly cerebellar involvement (suggested by the early ataxia though now impossible to determine accurately due to the frequency of involuntary movements). We have no further relevant information concerning the possible pathogenesis of this disorder, and carotid arteriograms were declined.

\section{Summary}

The case histories of two sisters evincing a syndrome with onset in childhood of progressive choreoathetosis associated with similar symmetrical cutaneous telangiectasia are presented. The clinical pattern of this syndrome does not fit clearly into any of the previously defined diseases of childhood. Its aetiology is unknown.

\section{REFERENCES}

Ajuriaguerra, J. de, Hécaen, H., Layani, F., and Sadoun, R. (1953). Rev. neurol. (Paris), 89, 81 .

Alexander, L. (1942). Res, Publ. Ass. nerv. ment. Dis., 21, 334.

Bush, J. A., Mahoney, J. P., Markowitz, H., Gubler, C. J., Cartwright, G. E., and Wintrobe, M. M. (1955). J. clin. Invest., 34, 1766.

Cartwright, G. E., Hodges, R. E., Gubler, C. J., Mahoney, J. P. Daum, K., Wintrobe, M. M., and Bean, W. B. (1954). Ibid., 33, 1487 .

Creutzfeldt, H. G. (1920). Z. ges. Neurol. Psychiat., 57, 1.

Denny-Brown thalamic Nuclei. Oxford University Press, New York. (Rethalamic Nuclei. Oxford University Press,
printed from Oxford Loose-Leaf Medicine.)

Hallervorden, J., and Spatz, H. (1922). Z. ges. Neurol. Psychiat., 79, 254.

Herz, E. (1944). Arch. Neurol. Psychiat. (Chicago), 51, 319.

Hunt J. R. (1917). Brain, 40, 58.

Jakob, A. (1921). Z. ges. Neurol. Psychiat., 64, 147.

Lhermitte, J., Cornil, L., and Quesnel (1920). Rev. neurol. (Paris) 27, 262 .

, and McAlpine, D. (1926). Brain, 49, 157.

Löwenberg, K., and Hill, T. S. (1933). Arch. Neurol. Psychiat. (Chicago), 29, 1232 .

Merzbacher, L. (1910). Z. ges. Neurol. Psychiat., 3, 1.

Pelizaeus, F. (1885). Arch. Psychiat. Nervenkr., 16, 698.

Ross, R. T. (1955). Canad. med. Ass. J., 73, 17.

Scheftel, Y. (1931). J. nerv. ment. Dis., 74, 175.

Uzman, L., and Denny-Brown, D. (1948). Amer. J. med. Sci., 215,

Vogt, C., and Vogt, O. (1920). J. Psychol. Neurol., 25, 627 (Ergänzungsheft 3.

Wilson, S. A. K. (1912). Brain, 34, 295.

Winkelman (1923). Arch. Neurol. Psychiat. (Chicago), 10, 563. 